\title{
亀裂および節理系岩盤の進行性破壊の解析に関する研究
}

\author{
浜島良吉*.川井忠彦**.山下清明*** \\ 草深守人****. 山田俊雄 $* * * * *$
}

\section{Numerical Analysis for Progressive Failure of Cracked and Jointed Rock Masses}

\author{
Ryokichi HAMAJIMA, Tadahiko KAWAI, Kiyoaki YAMASHITA, \\ Morito KUSABUKA and Toshio YAMADA
}

\begin{abstract}
Rock mass usually have cracks and joints, and can be considered anisotropic. Many numerical and experimental studies have been made on the mechanical properties. However the method of numerical analysis which can fully express the behaviour of such anisotropic rock mass with such discontinuities has not yet been developed. Recently the necessity of large scale excurvations and consequently establishment of an effective method of analysis is considered urgent to clarify the mechanical properties of jointed and cracked rock media.

This paper is based on the "rigid body spring models" proposed by Kawai, in which the elements themselves are assumed to be rigid and they are connected by two types of springs distributed over their interfase boundaries. Using the Mohr-Coulomb's failure criterion and considering the effect of contact as well as separation on the two points of interface boundaries of each elements, the perfect elasto-plastic analysis was carried out basing on the initial stress method.

In this paper the following results were obtained.

(1) Homogeneous and anisotropic mechanical characteristics of materials can be obtained by random or anisotropic discretization.

(2) In some cases of cracked rock masses, the crack propagates by slow stable fracture, while such as in splitting tensile test, it causes an instantaneous unstable fracture. This two modes of fracture are verified by numerical analysis.
\end{abstract}

(3) Fracture pattern results for jointed rock are good agreement with experimental and numerical results.

\section{1. まえがき}

岩盤の強度特性がとこに含まれる亀裂や節理に支配さ れることから，こうした不連続性岩盤に対する実験およ び解析がなされている。こうした不連続性岩盤の解析は 次のふたつに分けて考自らよう。

1）岩盤内に含まれる不連続性を考慮した不連続体解 析

\footnotetext{
* 埼玉大学工学部

***東京理科大学工学部

**** 法政大学工学部

***** 間組技術研究所

****** 非線形力学研究所
}

2）岩盤内に含まれる不連続性を考慮した構成則を用 いた連続体としての有限要素解析

ここで前者についてはさらに次のふたつにわけられよ $\zeta 。$

a) ジョイント要素を用いた有限要素解析 ${ }^{1), 2), 3)}$

b）要素を剛と仮定した不連続解析 ${ }^{4), 5), 6), 7) ~}$

ジョイント要素を用いた Goodman の解析法1) は不連 続面が既知の場合は有効に適用され得るが，亀裂性岩盤 や節理系岩盤のように任意面に亀裂およびすべりの進展 を考慮した解析が必要である場合には必ずしも適当であ るとはいえない。

これに対し Cundall4) は要素を剛と仮定し岩盤のトッ プリング破壞の解析を行った。しかし個々の要素の運動 

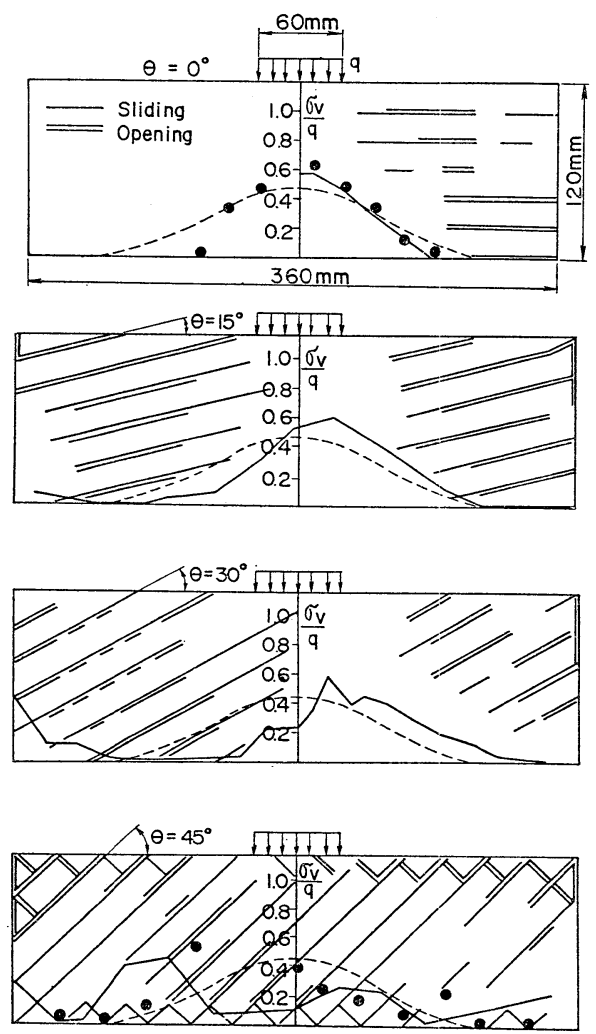

- Numerical (discontinuity)

Numerical (continuity)

図-1 不連続性基盤の反力分布 ${ }^{7)}$

を基に解析を和こなっていることからトップリング破壊 のよらな要素のばらばらの運動を扱ら問題には適してい るが拘束圧の作用する岩盤の解析には必ずしも適当であ るとはいえない。これに対し川井5) は剛体バギモデル (RBSM) を提案した。

また浜島等7) は剛体バネモデルを用い節理系岩盤の応 力伝達特性に対する解析を行い光弾性実験結果との良い 対応を示している。図-1 はこれらの解析例の一部であ るが，柱状節理面が水平面となす角度 $\theta$ の大きさが増す につれて, 岩盤底部の反力のピークは右方へ移動してゆ き $\theta=45^{\circ}$ に扣いてピーク位置が右から左へ飛び移って いる。これは節理面のすべりに帰因するものであり，一 種の力学的不安定現象を応力伝幡特性の立場から論じた ものであるが，亀裂および節理系岩盤の進行性破壊に拉 ける強度, 変形特性に対しては何も論じていない。本研 究においては以下に示すよらな亀裂和よび節理をモデル 化したモデル実験および解析を行い本解析の不連続性岩 盤の進行性破壊解析への適用性を明らかにする。
（1）迅速に亀裂が伝幡する不安定破壞

（2）多亀裂岩石材料の亀裂進展と破壊

（3）多節理岩石材料のすべりによる進行性破壊

また，(1)，(2)，(3) に括いては石膏材料を用いた供 試体が用いられ，実験は平面応力状態でなされる。ただ し亀裂および節理面の構成則はクーロンの摩擦則が適用 される。

\section{RBSM による解析}

浜島 $5^{7)}$ は節理を有する異方性岩盤の応力伝達特性に 対する研究を行い，節理間のすべりがこれら節理系岩盤 の力学特性に大きな影響を及ぼすことを明らかにした。 しかしこの解析に招いては図-2 (a) に示されるように 境界に一節点のみを有する要素が用いられていることか ら応力解析時に和けるモーメントによる応力成分項を十 分に表すことが出来ない。

これに対し 図-2 (b) に示されるような境界に 2 節点 を有する要素を用いることによりこれらの問題点を解決 することができる。

今，図-2 (b) に示されるように点， $m_{1} ， m_{2}$ 上の相 対変位ベクトル $\delta^{\prime T}=\left(\delta_{d 1}, \delta_{s 1}, \delta_{d 2}, \delta_{s 2}\right)$ と中点 $M$ 上の 相対変位ベクトル $\delta^{T}=\left(\delta_{d}, \delta_{s}, \phi\right)$ の関係が次の式で与 えられる。

$$
\boldsymbol{\delta}^{\prime}=\left\{\begin{array}{c}
\delta_{d 1} \\
\delta_{s 1} \\
\delta_{d 2} \\
\delta_{s 2}
\end{array}\right\}=\left(\begin{array}{ccc}
1 & 0 & l_{42} / 4 \\
0 & 1 & 0 \\
1 & 0 & l_{42} / 4 \\
0 & 1 & 0
\end{array}\right)\left\{\begin{array}{c}
\delta_{d} \\
\delta_{s} \\
\varphi
\end{array}\right\}=\boldsymbol{B}^{\prime} \boldsymbol{\delta}
$$

ここで 8 は要素の重心変位 $\boldsymbol{u}_{g}{ }^{T}=\left(u_{\mathrm{I}}, v_{\mathrm{I}}, \theta_{\mathrm{I}}, u_{\mathrm{II}}, v_{\mathrm{II}}, \theta_{\mathrm{II}}\right)$ を用いることにより次のように与えられる。

$$
\boldsymbol{\delta}=\boldsymbol{B} \boldsymbol{u}_{g}
$$

式（1）（2）を用いることにより，次式となる。

$$
\boldsymbol{\delta}^{\prime}=\overline{\boldsymbol{B}} \boldsymbol{u}_{g}
$$

\section{ここで $\bar{B}=B^{\prime} B$}

図-2 に示されるように境界面上の垂直応力と接線応 力は次のように相対変位 $\boldsymbol{\delta}^{\prime}$ によって表わされる。

$$
\begin{aligned}
& \boldsymbol{\sigma}=\left\{\begin{array}{c}
\sigma_{d 1} \\
\tau_{s 1} \\
\sigma_{d 2} \\
\tau_{s 2}
\end{array}\right\}=\left(\begin{array}{ccc}
k_{d 1} & & \\
& k_{s 1} & 0 \\
0 & k_{d 2} \\
0 & & k_{s 2}
\end{array}\right)\left\{\begin{array}{c}
\delta_{d 1} \\
\delta_{s 1} \\
\delta_{d 2} \\
\delta_{s 2}
\end{array}\right\} \frac{1}{h} \\
& =\boldsymbol{D} \frac{\boldsymbol{\delta}^{\prime}}{h}=\boldsymbol{D} \boldsymbol{\varepsilon}^{\prime}
\end{aligned}
$$

ここで， $k_{d}, k_{s}$ はそれぞれ垂直及び接線バネ剛性であ る。仮想仕事の原理より次式が得られる。 

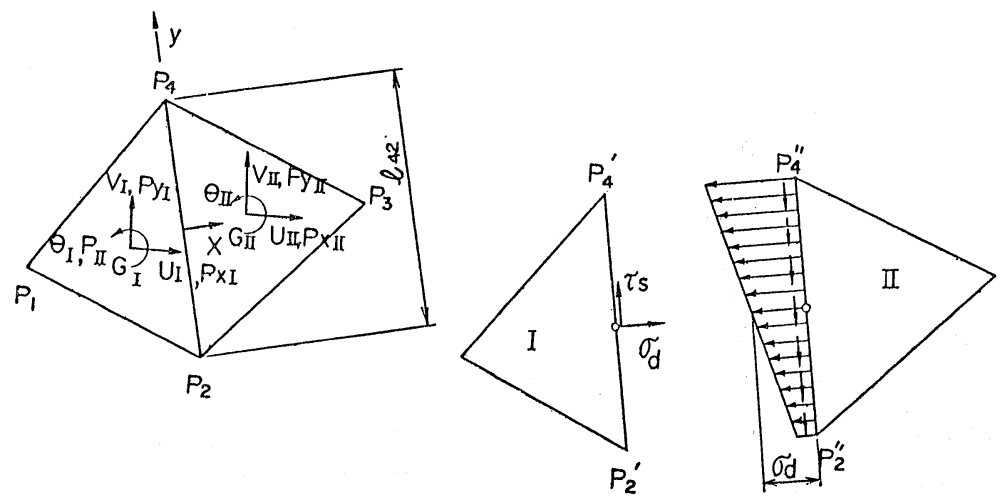

（a）境界一節点要素
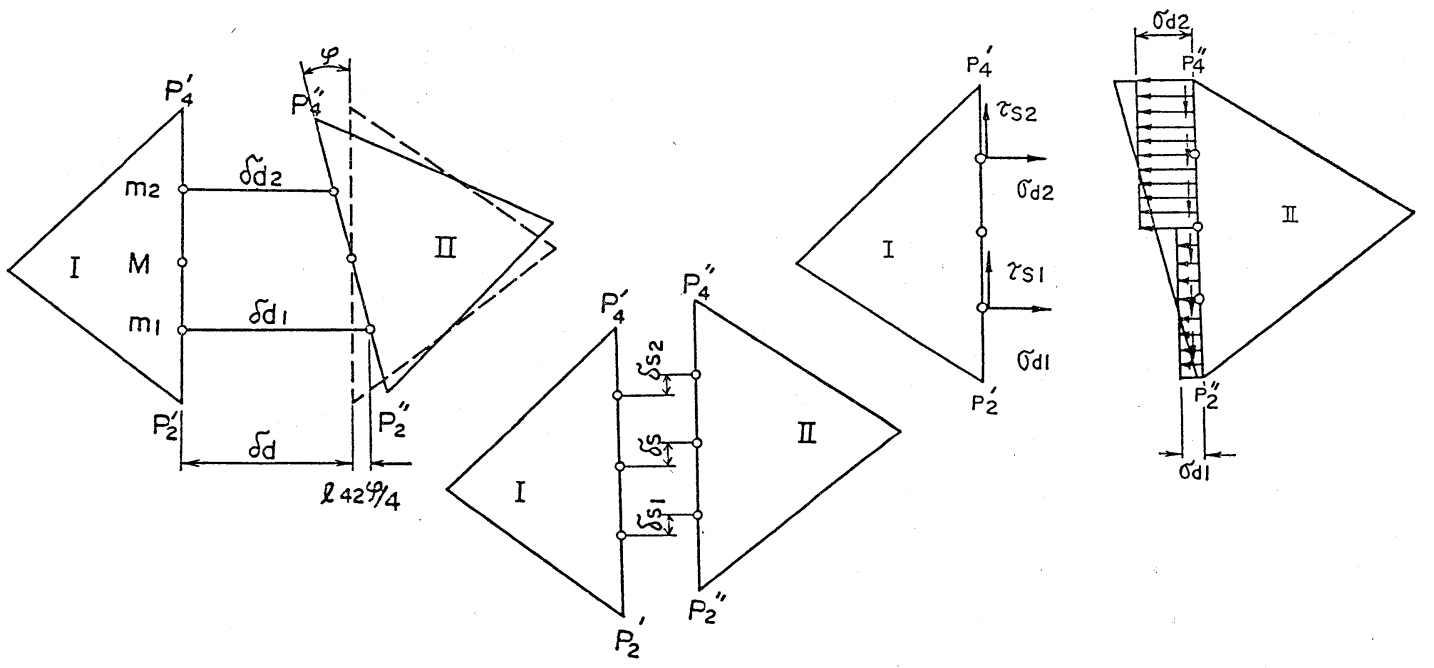

（b）境界二節点要素

図-2 剛体バネモデル

$$
\left\{\boldsymbol{u}_{g}\right\}^{T} \boldsymbol{T}=\iiint\left\{\boldsymbol{\varepsilon}^{\prime *}\right\}^{T} \boldsymbol{\sigma} d v
$$

ここで $\boldsymbol{T}$ は要素の重心に作用するカベクトルであり次 式で与えられる。

$$
T^{T}=\left(P_{X \mathrm{I}}, P_{Y \mathrm{I}}, G_{\mathrm{I}}, P_{X \mathrm{II}}, P_{Y \mathrm{II}}, G_{\mathrm{II}}\right)
$$

結局, カベクトルと相対変位ベクトルの間の関係は

$$
\boldsymbol{T}=\bar{B}^{T} \boldsymbol{K} \bar{B} u_{g}
$$

$$
\text { ここで }
$$

$$
\boldsymbol{K}=\frac{t l_{42}}{2 h} \boldsymbol{D}
$$

$t$ と $l_{42}$ は境界面の厚さと長さである。

境界面上の解放応力は次式のように仮想仕事の原理に

より解放力 $\boldsymbol{T}$ に関係づけられる。

$$
\left\{\boldsymbol{u}_{g}{ }^{*}\right\}^{T} \boldsymbol{T}=\iiint\left\{\boldsymbol{\varepsilon}^{\prime *}\right\}^{T} \boldsymbol{\sigma} d v
$$

結局，解放力 $\boldsymbol{T}$ は次のようになる。

$$
\boldsymbol{T}=\frac{t l_{42}}{2} \overline{\boldsymbol{B}}^{T} \boldsymbol{\sigma}
$$

\section{3. 構成方程式}

\section{1 平面応力場における母材の構成方程式}

降伏関数がドラッガー・プラッガーの関係式により与 学らると仮定する。

$$
\begin{gathered}
f=a J_{1}+\sqrt{J_{2}}-K=0 \\
\text { ここで } J_{1}=\sigma_{i i} \\
J_{2}=S_{i j} S_{i j} / 2, \quad S_{i j}=\sigma_{i j}-\sigma_{k k} \delta_{i j} / 3
\end{gathered}
$$

又, 平面ひずみ状態に执いて式（11）がモール・クーロ ンの直線式となることから係数 $a, K$ は内部摩擦角 $\phi$, および粘着力 $c$ を用いて次式で与えられる。 


$$
\alpha=\frac{\tan \varphi}{\sqrt{9+12 \tan ^{2} \phi}}, \quad K=\frac{3 c}{\sqrt{9+12 \tan ^{2} \phi}}
$$

今, 要素の局所座標系 $x, y, z$ を図-2 のように選 ぶ。平面応力場, 即ち $\sigma_{z}=\tau_{y z}=\tau_{z x}=0$ に打いて

$$
\begin{aligned}
f= & \alpha\left(\sigma_{x}+\sigma_{y}\right) \\
& +\frac{1}{\sqrt{3}}\left(\sigma_{x}^{2}+\sigma_{y}^{2}-\sigma_{x} \sigma_{y}+3 T_{x y^{2}}\right)^{1 / 2}-K=0
\end{aligned}
$$

（但し $\sigma_{x}=\sigma_{d}, \tau_{x y}=\tau_{s}$ とする）

ここで要素の境界に沿ら方向の变位成分は要素が剛で ある仮定から零となる。これより，関連流れ則の仮定か ら次の条件が必要となる。

$$
\frac{\partial f}{\partial \sigma_{y}}=0
$$

これより降伏関数 $f$ は次のようになる。

$$
f=\frac{3}{2} \alpha \sigma_{x}+\sqrt{1-3 \alpha^{2}} \sqrt{\frac{1}{4} \sigma_{x^{2}}+\tau_{x y^{2}}}-K=0
$$

こうして降伏関数は境界面での法線応力 $\sigma_{x}$ とせん断 応力 $\tau_{x y}$ のみの関数として表わされた。式 (15) はさら に次式のように変換することが出来る。

$$
\frac{\left(\sigma_{x}+\frac{6 \alpha K}{1-12 \alpha^{2}}\right)^{2}}{\frac{4 K^{2}\left(1-3 \alpha^{2}\right)}{\left(1-12 \alpha^{2}\right)^{2}}}+\frac{\tau_{x y}{ }^{2}}{\frac{K^{2}}{1-12 \alpha^{2}}}=1
$$

式（16）は楕円の方程式であり棈円の中心が原点より圧 縮側に $6 \alpha K /\left(1-12 \alpha^{2}\right)$ だけずれている。

ここで $\alpha$ の領域は $0^{\circ} \leqq \varphi \leqq 90^{\circ}$ であることより

$$
0 \leqq \alpha \leqq 1 / \sqrt{12}
$$

となる。式（16）において次の場合を洘える。

(a) $\quad \alpha=0$

$$
\frac{\sigma_{x^{2}}}{4 K^{2}}+\frac{\tau_{x y^{2}}}{K^{2}}=1, \quad K=c
$$

これは金属の場合におけるVon・Mises の基準に対応 乙，降伏曲線は原点に中心を持つ楕円となる（図-3）。 ここで一軸圧縮（または引っ張り）の降伏応力を $\sigma_{\eta}$ と すれば $2 c=\sigma_{\eta}$ であり, 純粋せん断時の降伏応力 $\tau_{\eta}$ は $\tau_{\eta}=c=\sigma_{\eta} / 2$ となる。

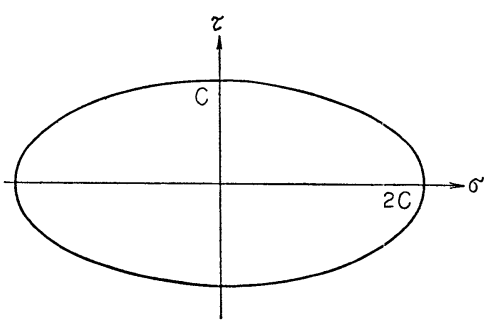

困-3 楕円降伏曲面 (b) $\alpha \rightarrow 1 / \sqrt{12}$

棈円の長軸を $a$, 短軸を $b$ とすると，

$$
\begin{aligned}
& a^{2}=\lim _{\alpha \rightarrow 1 / \sqrt{12}} \frac{4 K^{2}\left(1-3 \alpha^{2}\right)}{\left(1-12 \alpha^{2}\right)^{2}} \rightarrow \infty, \\
& b^{2}=\lim _{a \rightarrow 1 / \sqrt{12}} \frac{K^{2}}{1-12 \alpha^{2}} \rightarrow \infty
\end{aligned}
$$

したがって $\varphi$ が $90^{\circ}$ に近づくほど弾性領域が広がり 降伏しづらくなる。

(c) $K \rightarrow \infty$

$a^{2} \rightarrow \infty, b^{2} \rightarrow \infty$ となり粘着力の増加に伴い降伏曲面が 広がることを示している。

さて, 式 (13) で定数 $\alpha, K$ を平面ひずみ状態にお けるモール・クーロンの直線式から内部摩擦角 $\varphi$, 执よ び粘着力 $c$ をもらいて定めたが，これら $c ， \varphi$ を近似 的に図-4 に示されるような圧裂試験および一軸圧縮試 験結果から以下のように定める。

$$
c=\frac{\left|\sigma_{c}\right|}{2 \sqrt{m-3}}, \quad \varphi=\sin ^{-1} \frac{m-4}{m-2}, \quad m=\left|\frac{\sigma_{c}}{\sigma_{t}}\right|
$$

ここで $\sigma_{c}$ ：一軸圧縮強度

$\sigma_{t}$ : 圧裂試験に拉ける引っ張り強度

式 (16) に式 (13)，（18）を代入することにより降伏曲 面は図-5 に示されるように, $\tau_{x y}=0$ において一軸圧

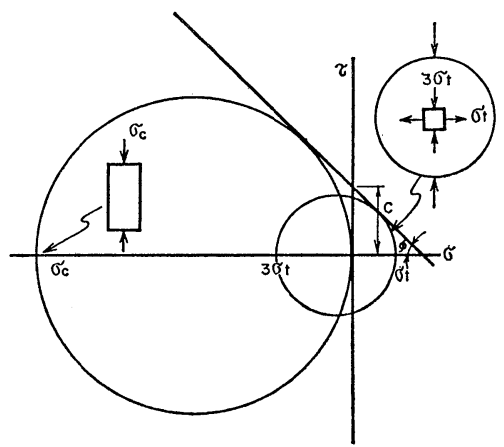

図-4 材料定数 $c$ と $\phi$ に対する近似决定法

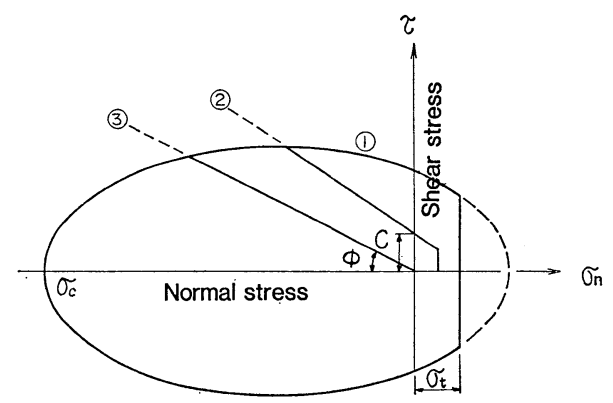

図-5 母材と不連続面の降伏曲線 
縮強度 $\sigma_{x}=\sigma_{c}$ となることがわかる。ここで引っ張り領 域に怙いては図-5 で示されるようなテンションカット を用いるものとする。

\section{2 不連続面に対する構成則}

亀裂面扣よび節理面に拈ける構成則は一面せ九断実験 より定められ，これは次のクーロンタイプの構成則を満 足する。

$$
f=|\tau|+\sigma \tan \varphi^{\prime}-c^{\prime}=0
$$

ここで $\varphi^{\prime} ， c^{\prime}$ は内部摩擦角および粘着力である。

\section{4. 初期応力法による弾塑性解析 ${ }^{9}$}

解析に和いて塑性ポテンシャルと降伏関数が等しいと した関連流れ則を仮定し，また完全弾塑性を仮定する。 ただし式 (4)に和いて与えられる境界面のバネ定数 $k_{a}$, $k_{s}$ に対しては次のようになる。

連続部（母材）

$$
k_{d}=\frac{E}{1-\nu^{2}}, \quad k_{s}=\frac{E}{1+\nu}
$$

ここで $E$ は一軸圧縮試験から得られるヤング係数で ありンはポアソン比である。

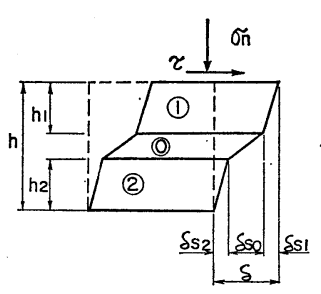

(a)

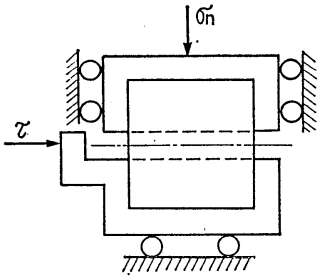

(b)
困-6 不連続面のせん断剛性決定のためのせえ断 試験

\section{不連続部}

図-6 (a) に示されるょうに要素 (1) と (2) の間に弱 面 (0) が挿入されている場合を考学る。要素 (1)，(2)の せん弾剛性を式 (20) で与えられる $k_{s 1}, k_{s 2}$ とする。 そして弱面のせん弾剛性は $k_{s 0}$ であり一面せん弾実験か ら定められる。これより弱面と (1)，(2) を含む要素の等 価せん弾剛性 $k s$ は次のように定められる。

$$
d \tau=k_{s 1} \frac{d \delta_{s 1}}{h_{1}}=k_{s 2} \frac{d \delta_{s 2}}{h_{2}}=k_{s 0} d \delta_{s 0}=k_{s} d \delta_{s}
$$

ここで $h_{1}, h_{2}$ は要素 (1)，(2) の重心から弱面までの 長さである。

$$
\text { ここで }
$$

$$
d \delta_{s}=d \delta_{s 1}+d \delta_{s 2}+d \delta_{s 0}
$$

である。ただし $d \delta_{s 1}, d \delta_{s 2}, d \delta_{s 0}$ はそれぞれの要素 (1)，
(2) 及び弱面のせん断変位である。

これより

$$
k_{s}=\frac{1}{h_{1} / k_{s 1}+h_{2} / k_{s 2}+1 / k_{s 0}}
$$

同様にして等価垂直剛性 $k_{a}$ は次式で与兄られる。

$$
k_{d}=\frac{1}{h_{1} / k_{d 1}+h_{2} / k_{d 2}+1 / k_{d 0}}
$$

ただし $k_{d 1}, k_{a 2}, k_{a 0}$ は要素 (1)，(2) 及び弱面の垂直 剛性であり， $k_{d 1}, k_{d 2}$ は式 (20) で与兄られる。 $k_{a 0}$ の 值は弱面を有する岩石供試体を用いた一軸圧縮試験から 決定される ${ }^{10)}$ 。そしてこの值は一般に垂直応力 $\sigma_{n}$ の関 係として与兄られるがここでは $k_{d}, k_{s}$ は一定と仮定し て解析を行っている。

\section{1 解の収束}

図-5 に示されるように母材の降伏曲面 (1), 粘着力を 有する不連続面に対する降伏曲面 (2)，そして粘着力を 持たない不連続面の降伏曲面 (3) が与兄られる。

ここで，母材抒よび不連続面に括いてクラックが発生 し，その後再接触する場合には (3) の降伏曲面を用いる。

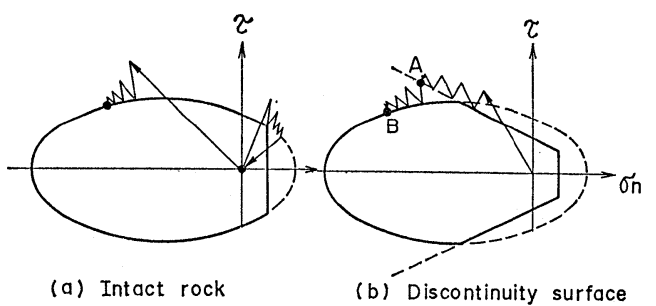

(a) Intact rock

(b) Discontinuity surface

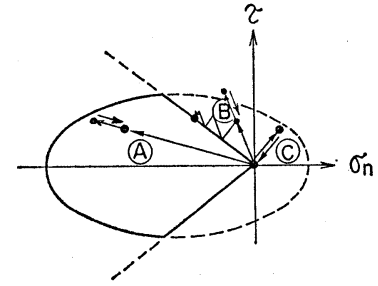

(c) Recontact of discontinuity surface

図-7 降伏曲面上での応力の収束状況

\section{a）母材の降伏}

四-7（a ）は母材の降伏曲面上での収束状態を示した ものである。引っ張り領域では限界引っ張り応力 $\sigma_{t}$ を 越えた場合にクラックが発生したとして境界面上の応力 を全て解放する。

b) 不連続面での降伏

図-7（b ）飞执いて不連続面の降伏曲面上の収束点が 母材の降伏曲面をこえた場合には, 母材の降伏曲面上で 収束するように応力を解放する。 


\section{c) 再接触}

図-7（c）に和いて応力経路 A は再接触したが降伏し ていない場合である。応力経路 B は再接触後の応力が降 伏曲面を越えた位置にあり, 応力解放により降伏曲面上 に収束した場合である。応力経路 Cは引張側に変形が進 んでいるので境界面の応力は全て解放される。ここで引 張領域における剛性は圧縮領域と同じとする。

\section{5. 解析結果}

\section{1 メッシュ分割が強度変形特性におよぼす影響}

RBSM による解析に抹いての問題点は解析結果がメ ッシニ分割に依存することである。そこで完全弾塑性材 料（降伏点応力 $\sigma_{Y}=14 \mathrm{MPa}$ ，ヤング係数 $E=2.1 \times 10^{5}$ $\mathrm{MPa}$ ，ポアシソン比 $\nu=0.3$ を仮定）について 図-8 に 示されるメッシュ分割に拈ける際の特性を調べることに する。

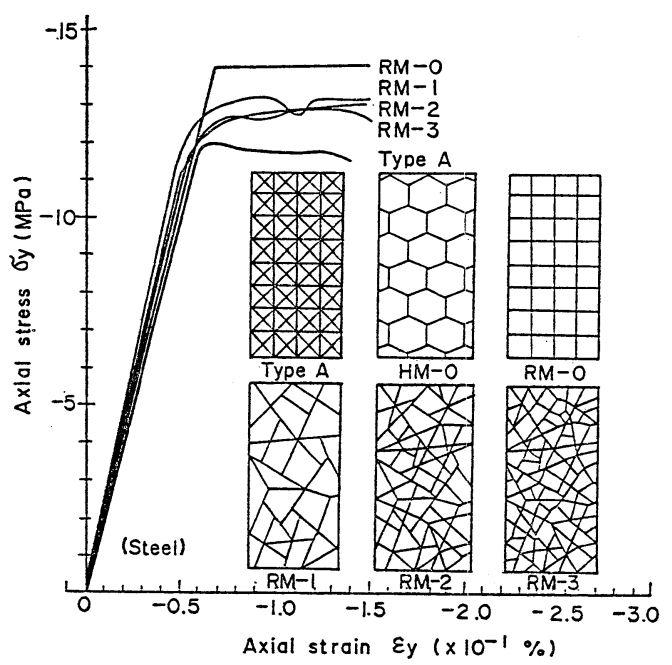

困-8 強度に及ぼす要素分割の影響

図-8 は方向性を有するメッシュ分割 Type A, HM0，RM-0 と方向性を有しないRM-1, RM-2, RM-3 に対する鋼材の一軸圧縮強度変形特性である。この場合 には RM-0 が仮定した材料の $\sigma_{y}-\varepsilon_{y}$ 関係を正確に表 し，Type-A のピーク強度は正解より約 15\% ほど小さ い。これに対しランダムメッシュ分割 RM-3 では正解 より約 $8 \%$ ほど小さい。これについて構成則の面から 考察してみよう。図-3 の降伏曲面において, 純せん断 応力状態に和いて $\tau_{\eta}=\sigma_{\eta} / 2\left(\tau_{\eta}=\right.$ 降伏せん断応力, $\sigma_{\eta}=$ 一軸降伏応力）となって和り，これはTresca の条件に 対応する。これに対して修正係数 $\beta=2 / \sqrt{3}$ を乗ずるこ

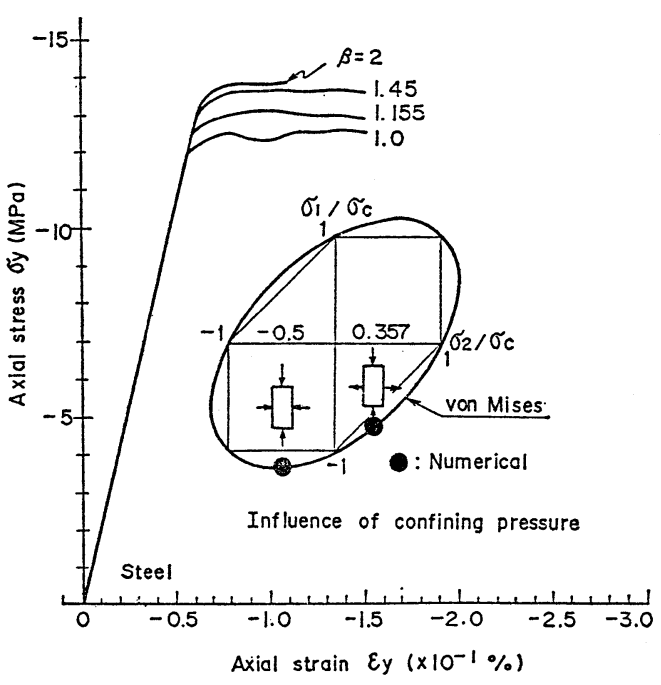

図-9 修正降伏関数による解析結果

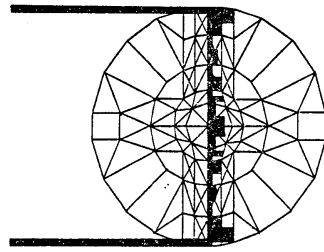

Stress distribution

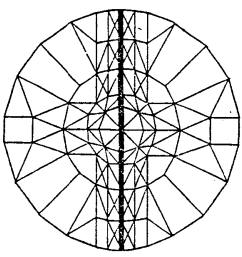

Fracture

(a) $\psi=4^{\circ}$

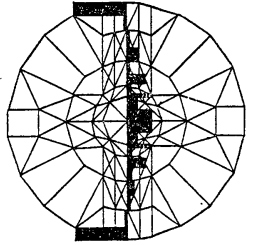

Stress distribution

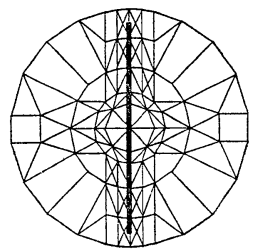

Fracture

(b) $\psi=12^{\circ}$

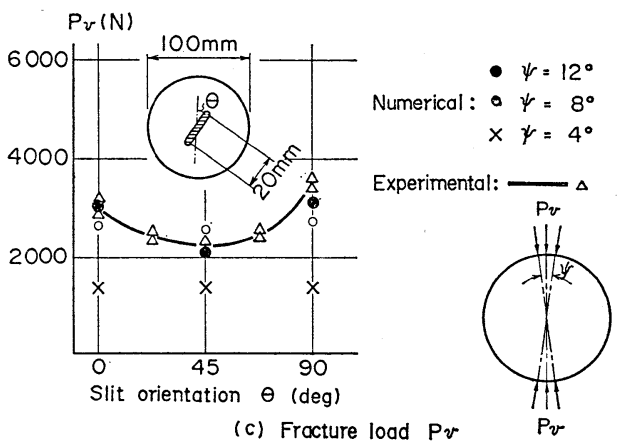

図-10 圧裂試験に対する結果 
とにより Von Mises の降伏条件 $\tau_{\eta}=\sigma_{\eta} / \sqrt{3}$ となるよ らに修正した場合，結果は図-9のようになりVon Mises の降伏条件に対する理論解に対し約 $6 \%$ の誤差 となる。 $\beta=2$ に打いてほぼ Von Mises の理論解と一 致するが，この值を用いて 図-9 に示すように二軸応力 状態を計算するとVon Mises の降伏関数上にのり,こ れよりランダムメッシュ分割をすることにより等方性の 性質を表現できることがわかる。

\section{2 急速に亀裂が伝幡する不安定破壞}

図-10 は石亮円板の圧裂試験㐨よび解析結果である。 水と石膏の重量比 $1: 1.6$ の石亮供試体（直径 $100 \mathrm{~mm}$, 厚さ $50 \mathrm{~mm}$ ) を用い，圧裂試験は円孤圧子（供試体半径 $50 \mathrm{~mm}$ に対し円孤圧子半径 $150 \mathrm{~mm}$ ) を用いた載荷がな されている8)。解析に際しては 図-10 c に示されるよう な径方向の分布荷重によるものとする。
図-10 a, b は載荷角度 $\psi=4^{\circ}, 12^{\circ}$ の場合に拈ける 鉛直断面上の水平応力（着色部）特よび破断面（太実線 部）を示している。ここで注目すべきことは, 載荷角度 が小さい場合 $\left(\psi=4^{\circ}\right)$, 亀裂は載荷部（上, 下端部）か ら中央部に向けて進展し, $\phi=12^{\circ}$ の場合亀裂は中央部 から上下端部に向って進行する。実験において, これら の亀裂は一瞬のらちに進展するが解析結果に招いて子亀 裂は全断面同時に生じ，急速に亀裂が伝幡する不安定破 壞性状をよく表現している。ただし, 図-10 a, b の応力 分布は破断が生ずる直前のものを示して和り， $\phi=4^{\circ}$, $12^{\circ}$ 相方共, 載荷板直下（直上）では圧縮力を生じて $\phi=4^{\circ}$ に和いては隣接要素において最大引張応力 $\sigma=$ $2.47 \mathrm{MPa}$ を生じここょり引張破壊を生ずることを示し ている。これに対し， $\phi=12^{\circ}$ の場合に执いては円板中 央部に括いて最大引張応力 $\sigma=2.47 \mathrm{MPa}$ を生じここょ

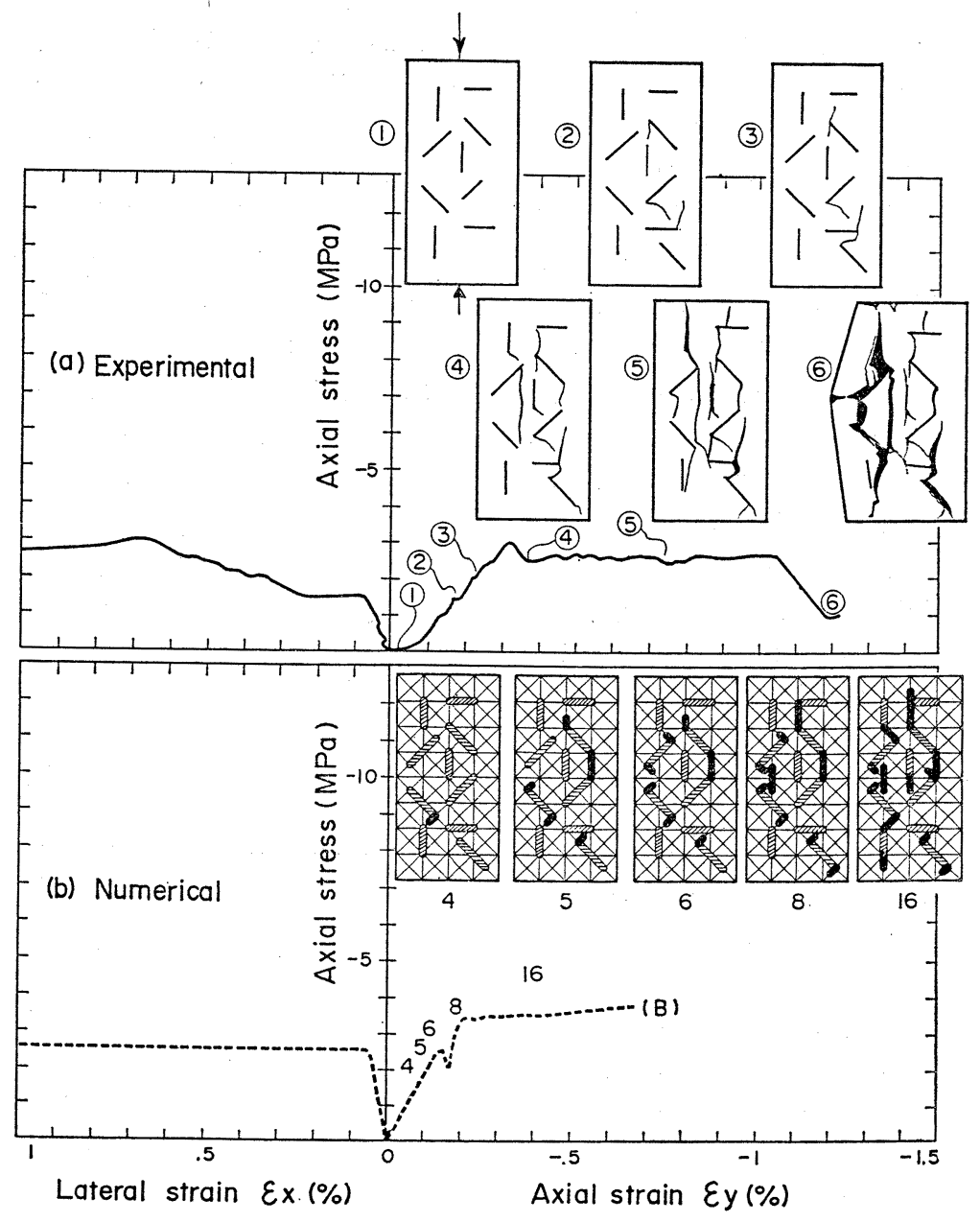

図-11 刍裂性岩盤モデルの進行性破壞 
り引張破壊が生じることを示している。

図-10 cは円板中央部にスリット（長さ $20 \mathrm{~mm}$ )を入 れた場合の解析結果および実験結果を示している。ここ でスリットは厚さ $0.8 \mathrm{~mm}$ の紙を挿入し，石高の固結 前に紙を引き抜いて作成した。解析結果は $\phi=4^{\circ}, 8^{\circ}$, $12^{\circ}$ の 3 種類についてなされたが $\phi=4^{\circ}$ の場合に対し てはスリット角度 $\theta$ の変化によらず強度が一定值とな る。これに対し， $\phi=8^{\circ}, 12^{\circ}$ の場合スリット角度 $\theta$ に より強度が変化し， $\theta=45^{\circ}$ に括いて最小值を示して特 り, 実験結果は $\phi=12^{\circ}$ の場合とほぼ一致している。実 験後の円孤圧子と石膏円板との接解部分は拈よと $\phi=$ $12^{\circ}$ に対応している。岩石の引張試験に対して一軸引張 試験のかわりに压裂試験がよく用いられるが，円板中央 部からの亀裂発生が必要とされている。載荷板として円 孤圧子を用いることによりこうした条件は満たされる が，円孤圧子の円孤の曲率半径の大きさと強度との関係 についてさらに詳細な検討が期待されよう。

\section{3 多亀裂岩石材料の亀裂進展と破壊}

図-11 a, b は多龟裂岩石モデルの実験結果和よび解析 結果である。モデルは石膏供試体（幅 $100 \mathrm{~mm}$, 高さ $200 \mathrm{~mm}$, 厚さ $50 \mathrm{~mm}$ ) を用い, 水, 石亳重量比は 1 ： 1.6 である。亀裂部は長さ $20 \mathrm{~mm}$, 厚さ $0.8 \mathrm{~mm}$ の紙 を石膏を型枠に流入直後に挿入することにより作成し た。供試体は 1 時間後に型枠から取りはずし $20^{\circ} \mathrm{C}$, 湿 度 $50 \%$ で 3 週間養生した後実験を行っている。石高供 試体重量は 1 週間 10日で注注一定となり，压縮強度も 一定となるが本実験では 3 週間の養生を行った。ただし 1 週間後に供試体を所定の厚さ $(50 \mathrm{~mm})$ になるように 端面を切断している。また厚紙を挿入した状態で実験を 行っているが石膏と厚紙の間の摩擦を変化させるため厚 紙にシリコングリスを塗布したものとしないものとの比 較を行い，一軸圧縮試験では強度の差は認められなかっ た。これは亀裂の鉛直軸からの角度 $\theta$ が $\theta=0^{\circ}, 45^{\circ}$, $90^{\circ}$ の及であり, 一軸載荷試験に批いては龟裂部の摩擦 強度（せん断強度）が支配的でないところによる。

図-11 a は一軸圧縮試験結果であり，軸ひずみ $\varepsilon_{y}$ は 供試体の軸方向変位を高さ $(200 \mathrm{~mm})$ で除した值を用い ている。供試体上下端部には厚さ $40 \mathrm{~mm}$ の載荷板を用 い, 載荷は $20 \mathrm{t}$ の変位制御試験機によっておこなった。 また供試体と載荷板の間の摩擦をとるため $0.2 \mathrm{~mm}$ 厚の テフロンシート両面にシリコングリスを塗布したものを 挿入している。軸方向变位は下載荷板下面と上載荷板上 面の間の変位（2 ケ所）を測定しているが，本実験に先 立ちスリットのない供試体にひずみダージを貼付し, 変位測定から求めた軸ひずみと同じひずみ量となるこ
とを確認している。また横ひずみは，高さ中央部の両側 面部に抢いて変位を測定し，これを供試体幅 $(100 \mathrm{~mm})$ で除したものとする。実験結果をみるとステップ (2) に 抒いて亀裂の発生がみられるが，鉛直方向ひずみ $\varepsilon_{y}$ が わずかに変動しているのに比し横方向ひずみ $\varepsilon_{x}$ が大き く変化している。ステップ (4) に抽いて強度が少し低下 し，ステップ (6)に执いて最終的な破断に至っている。 図-11 b は計算結果であり供試体内の斜線部は亀裂押入 部を，そして黒色部は亀裂進展部を示す。計算結果をみ るとステップ (4) (実験結果に和けるステップと異る) に打ける亀裂の発生では強度, ひずみ量共, 汪とんど変 化が文られない。ステップ (5) の亀裂発生に括いて強度 拉よび軸方向ひずみ $\varepsilon_{y}$ が少し変化するのに比し, 横方 向ひずみの著しい変化がみられる。ステップ (8) 以後, 強度は添湆横ばいとなって拈り実験結果にみられるよう なステップ (6) に淤ける破断による強度低下はみられな い。これは本解析法が完全弾塑解析を行って和り, 強度 のひずみ軟化特性を考虑していないことによる。また計 算結果と実験結果で亀裂の発生位置, 順序が必ずしも一 致していないが最終的な破断性状は傾向的には近いもの といえよう。また横方向への大きならくらぬは連続体と して考党た場合のポアッソン比による効果では説明のつ かないものであり，不連続体としての解析により初めて 評価しらるものである。

図-12 は種々の亀裂本数を有する場合の石亭供試体を

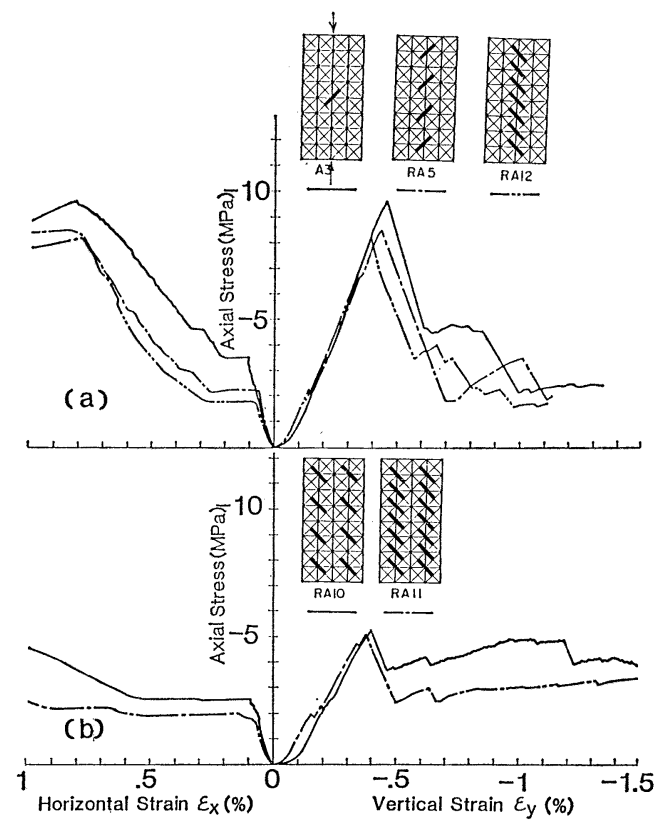

図-12 亀裂数と配置の違いによる強度变化 
用いた実験結果であるが，図-12 a は龟裂が一列に配置 された場合であり亀裂本数により強度はそれ程大きく变 化しない。これに対し図-12 b は亀裂が二列に配置され た場合であり一列の場合に比し強度は約半分になってい る。このように亀裂性岩盤では亀裂の配置が大きな影響 を及ぼすことがわかる。眓-13 は亀裂本数を変化させた 場合の一軸圧縮試験の結果と計算結果の比較であり亀裂 本数 $n=1,2,3,4,7$ 本については一列に配置したも の， $n=10$ 本については 因-11 a の配置である。ここ で縦軸は亀裂のない場合の供試体の一軸圧縮強度 $\sigma_{c}$ で 除して, 無次元化されている。一列の場合に执いて強度 は比較的変化がゆるやかであるが亀裂本数 10 本のラン ダム配置の場合には強度が著しく低下している。計算結 果はこうした傾向を表現しているといえよう。

図-14 は亀裂長さの变化による一軸圧縮試験と計算結 果の比較であるが亀裂長さの増大による強度の低下を計 算結果はよく表しているとい兄る。上記のように亀裂性 岩盤に打いては亀裂の数のみでなくその配置, そして亀 裂長が強度に影響を及ぼすが，本解析法は傾向的にはこ らした特性を示すことが出来るといえる。しかしピーク

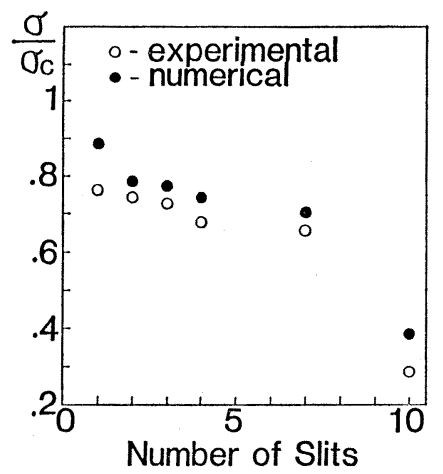

四-13 笠数の変化による強度変化

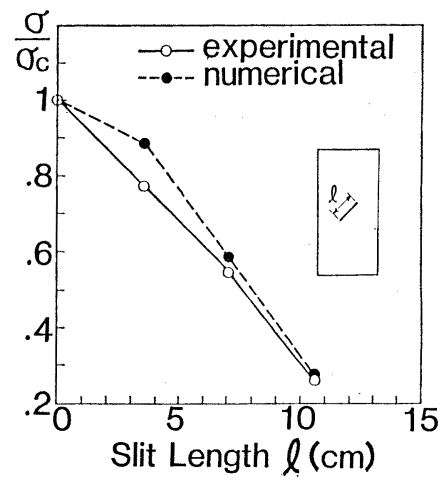

図-14 亀裂長の変化による強度変化
強度後の強度特性については材料のひずみ軟化特性を考 慮した解析が必要である。また詳細な刍裂進展を追跡す るにはもっと細かいメッシュ分割が必要とされるが，本 解析に用いられた比較的粗いメッシュ分割でも，進行性 破壊の特性は表現しうるといえよう。

\section{4 多節理岩石材料のすべりによる進行性破壊}

図-15 は多節理岩石モデルの実験結果および解析結果 である。

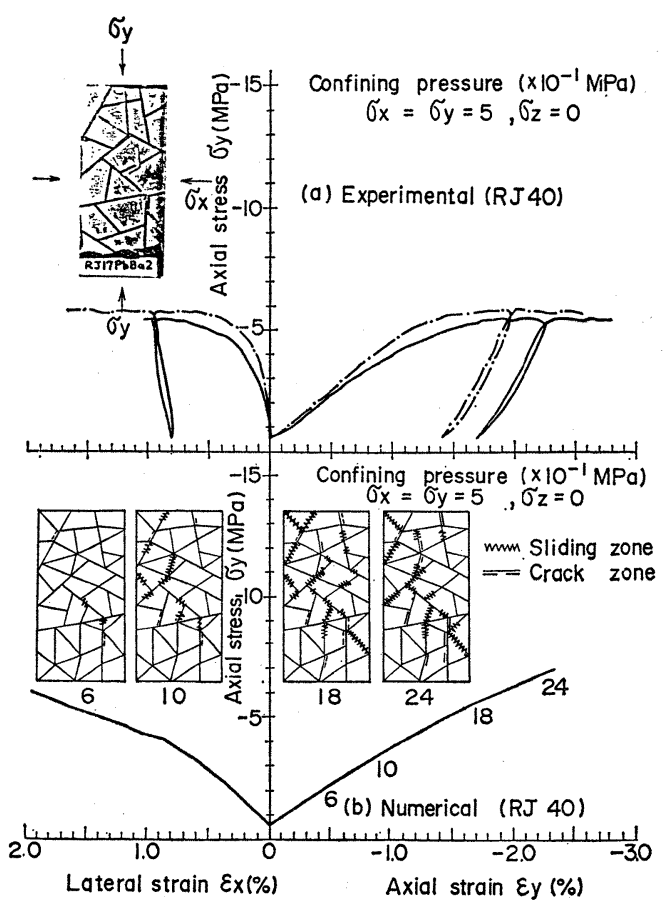

図-15 節理系岩盤モデルの進行性破壞

モデルは多亀裂岩石モデルと同じ石亳供試体（幅 100 $\mathrm{mm}$, 高さ $200 \mathrm{~mm}$, 厚さ $50 \mathrm{~mm}$ ) を刃厚 $2 \mathrm{~mm}$ のカッ ターで切断し, 型枠の中に入れ, 寸き間に水石高重量比 1:1 の石膏を流し込及固化後（1日後）型枠をはず 乙温度 $20^{\circ} \mathrm{C}$, 湿度 $50 \%$ で 3 週間養生後, 実験を行っ た。節理系岩石モデルに拉いては一軸圧縮試験ができな いため, プレッシャーバックを用いた二軸載荷試験を行 った。二軸載荷装置は供陚体の両傾にプレッシャーバ ックにより等分布圧を作用させることが出来, 油圧を用 い, $2 \mathrm{MPa}$ までの側圧載荷が可能である。横方向の変 位は, プレッシャーバックの高さ中央部で測定可能な端 子がプレッシャーバック外に出されている。図-15a は 節理により 40 要素に分割された石高供試体の二軸圧縮 試験結果（側圧 $\sigma_{x}=0.5 \mathrm{MPa}$ ）を示している。2 回の 
試験結果が示されているがほぼ一致して拉り良い再現性 を示している。図-5b はこの解析結果であり，軸荷重 の増加により節理のすべりが進展し，それに伴い剛性の 低下拉よび横方向へのふくらみが生じていることがわか る。また要素へ回転が生じることにより，すべりのみで なく節理部の開口が生じているが，実験值に比し横方向 へのふくらみが相当大きめに出ている。これは実験にお いてプレッシャーバックがある程度剛性を有して扮り幾 分，横方向の変位が拘束され小さく出ているものと思わ れる。図-15 a の写真は最終的な破壊性状を示している （ただし 40 要素のモデルは判別が困難なため 17 要素の モデルが示されている)。実験結果と計算結果のすべり による破壊性状は傾向的には対応しているとい兄よう。

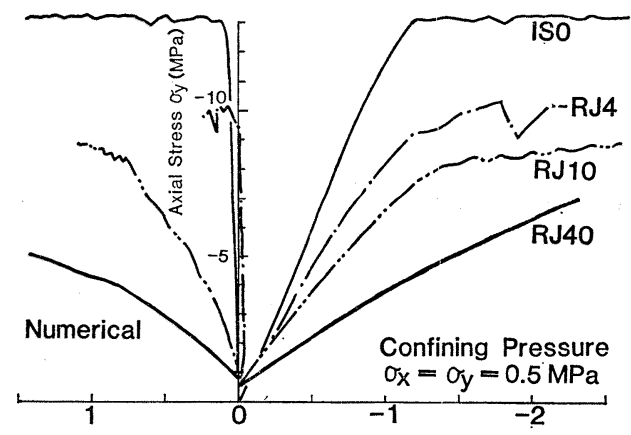

Horizontal Strain $\varepsilon_{x}(\%) \quad$ Vertical Strain $\varepsilon_{y}(\%)$

図-16 節理系岩盤モデルの解析結果

図-16 は節理のない場合 (ISO), 4 要素モデル (RJ 4), 10 要素モデル (RJ 10), 40 要素モデル (RJ 40) の計算結果である。節理のない場合の一軸圧縮強度は本 実験に用いた石毫モデルでは $\sigma_{c}=14 \mathrm{MPa}$ であり計算結 果と一致しているが，実験に括いては 図-12 と同様に ピーク強度に達した後, 急速な強度低下を示す。これに 対し計算結果では完全弾塑性的解析を行っているためピ 一ク後の強度低下はみられない。4 要素モデルに执いて 一部ブロックの引張破壊による応力解放によりわずかな 強度低下を示すが実際においては節理のない場合程では ないがピーク後の強度低下を示す。ただし要素数の変化 による剛性の変化はその物理的特性をよく表現している とい光る。また横方向へのふくらみに特いても，10 要 素モデルに和いて節理面のすべりにより急速に大きくな っていることがわかる。ただし，4要素モデルに执いて はブロックの回転の影響によりむしろ，変位測定面にお いて見掛け上圧縮ひずみが生じている。多節系岩石材料 の進行性破壞厄捛いてもピーク後の挙動を除き, 強度,
変形特性並びに破壊性状を本解析法は比較的よく表現し らるといえよう。

ところで上記解析に用いた材料定数はつぎのようであ る。

母材の石高に対しヤング係数 $E=1160 \mathrm{MPa}$ ，ポアッ ソン比 $\nu=0.25$, 圧裂引張強度 $\sigma_{t}=2.47 \mathrm{MPa}$, そして 亀裂部の $\sigma_{t}=0$, 内部摩擦角 $\phi=37^{\circ}$, 粘着力 $c=0$, 垂 直剛性 $k_{d}=423 \mathrm{MPa}$ ，せ九断剛性 $k_{s}=42 \mathrm{MPa}$ ，交た節 理部に対しては $\sigma_{t}=0.2 \mathrm{MPa}, c=0.4 \mathrm{MPa}$ を除いては 亀裂部と同じにした。ここで垂直剛性せん断剛性は垂直 応力 $\sigma_{n}$ により幾分变化するが一定とした。

\section{6. 結 語}

亀裂や節理等の不連続部を有する岩盤解析の進行性破 壊の解析法を確立することを目的として亀裂性岩艋，節 理系岩盤の特性を代表的に表すモデルに括いて実験拉よ び解析結果の比較を叔こない，以下の結果を得た。

(1) 境界 2 点要素を用いることによりモーメント応力の 解放が合理的になされらる。

（2）RBSM による解析に対応して平面応力状態の岩質 材料の構成則が棈円形状で表されることを示し，こ れに含まれる材料定数が近似的に圧裂試験からの引 張強度, 特よび一軸圧縮強度から決定できることを 示した。

（3） 2 つの要素の間に弱面 (不連続面) が存在する場合, この弱面を含んだ等価せん断剛性，等価垂直剛性を 定義した。これにより RBSM に抢いて計算上の弱 点であった変形特性を正確に解析可能となった。

（4）圧裂試験の数值解析結果から, 荷重載荷幅が小さい 場合，亀裂は載荷部から中央部に向けて進展し，荷 重載荷幅が大きい場合円板中央部から載荷部に向け て進展する。載荷幅が小さい場合載荷部での降伏が 進及压裂引張強度は小さ目に出る。压裂試験に和け る破断は瞬間的に生ずるが，解析結果もほとんぞ全 断面同時に近い形で進展することから, 本解析法 は，こうした急速に亀裂が伝幡する不安定破填にも 適用可能といえる。

（5）多亀裂の岩質材料は本数の久でなく配置，拉よび龟 裂の長さによっても強度が大きく変化するが，本解 析法はこうした特性を比較的良く表現することがで きる。特に一軸圧縮試験に泾いて, 亀裂の発生進展 に伴い横方向への著しいふくらみが生じるが，これ は連続体解析に叔けるポアッソン比による評価では 表現することができない。ただし，ピーク荷重後， 荷重低下を生ずるものに対しては材料のひずみ軟化 
特性を考慮する必要がある。

（6）多節理系岩質材料は，節理本数が少い間は弾性材料 に近い挙動を是するが節理本数が増すにつれ，節理 のすべりに伴う進行性破壊により，強度変形特性は 粒状材料のそれに近い性状を示すようになる。こう した性状を本解析法は比較的よく表現することがで きるが，節理でのすべり以外に母材の破壊を伴うも のについては材料のひずみ軟化特性を考慮した解析 が必要である。

（7）本解析に执いては弱面を含んだ等価せん断剛性，等 価垂直剛性を与えているが弱面不連続面は通常ラフ ネスを有し，このラフネスの大きさにより強度変形 特性が変化し著しい非線形性抒よび寸法効果を示 す。しかし逆にこれらを表現しうる定式化が可能で あれば本解析法により寸法効果等を有効的に表すこ とができよう。

（8）本解析法は要素分割を決定論的に与えているが，実 際の岩盤の特性を十分に評価しらるメッシュ分割が 必要となる。さらにメッシュ分割された要素の材料 特性についても，ささら亀裂や節理を評価した值を 与兄る必要がある。しかしこれらについては最近活 発な研究が進められて和り, これらは本解析法と相 まって不連続性岩盤の解析を一層有効なるのにする ことができよう。

\section{参 考 文 献}

1) Goodmann, R. E., Tayler, R. L. and Brekke, T. L. (1968): A model for the mechanics of jointed rock. J. Soil Mech. and Found. Div., Proc. A. S.C.E. SM3, pp. 637-659.
2) Zienkiewicz, O. C. and Dullage, C. (1970): Analysis of non-linear problems in rock mechanics with particular reference to jointed rock systems, Proc. 2nd Int. Cong. on Rock Mech. Sec. 8-14.

3) Kawamoto, T. and Takeda, N. (1978): An analysis of progressive failure in rock slopes, 3rd Int. Conf. on Numerical methods in Geomechanics, Achen, pp. 797-808.

4) Cundall, P. A. (1971): A computer model for simulating progressive large-scale movements in blocky rock system. Symposium on Rock Fracture, Nancy, France, October, Sec. 2-B.

5) Kawai, T. (1980): Some consideration on the finite element method, Int. J. for Numerical Methods in Engineering, Vol. 16, pp. 81-119.

6) Takeuchi, N. and Kawai, T. (1980): Limit analysis of soil and rock foundations by means of new discrete models-an analysis of a notention materials, Journal of the Seisan Kenkyu, Vol. 32, No. 6.

7) Hamajima, R. and Kawai, T. (1981): Stress transfer mechanism of the jointed rock media with strong anisotropy. J. of the Japan Society of Engineering Geology, Vol. 22-3, pp. 1-8.

8）浜島良吉，田村裕夫，草深守人（1983）：亀裂性岩 石材料の压裂引張強度, 第 18 回土質工学研究発表 講演集, pp. 767-768.

9) Zienkiewicz, O. C., Valliappan, S. and King, I. P. (1969): Elastoplastic solutions of engineering problems initial stress finite element approach. Int. J. for Numerical Methods in Engineering, Vol. 1, 75-100.

10) Bandis, S. C., Lumsdenm, A. C. and Barton, N. R. (1983): Fundamentals of rock joint deformation. Int. J. Rock Mech. Min. Sci. \& Geomech. Abstr., Vol. 20, No. 5, pp. 249-268.

（昭和 61 年 2 月 6 日受付，昭和 62 年 7 月 3 日受理） 